\title{
Short communication: Bacteriocin KC24 produced by Lactococcus lactis KC24 from kimchi and its antilisterial effect in UHT milk
}

\author{
E. J. Han, ${ }^{*}$ N.-K. Lee, ${ }^{*}$ S. Y. Choi, † and H.-D. Paik*1 \\ *Division of Animal Life Science and Bio/Molecular Informatics Center, Konkuk University, \#1 Hwayang-dong, Gwangjin-gu, Seoul 143-701, Korea \\ †Korea Food Research Institute, \#1201-62 Anyangpangyo-ro, Seongnam, Gyeonggi 463-746, Korea
}

\begin{abstract}
The severity of Listeria monocytogenes infections emphasizes the need for prevention or elimination of the pathogen from dairy products. Lactococcus lactis KC24, isolated from kimchi, exhibited an antimicrobial effect against food pathogens, including L. monocytogenes ATCC 15313. Lactococcus lactis $\mathrm{KC} 24$ was cultured in a 5 -L jar fermenter at $35^{\circ} \mathrm{C}$, and bacteriocin activity was maximal at $4 \mathrm{~h}$ of incubation and persisted for 20 h. Bacteriocin KC24 was inactivated by protease XIV, indicating that it has a proteinaceous nature. Bacteriocin activity was maintained at $\mathrm{pH} 3.0$ to 9.0 and at temperatures of 50 to $121^{\circ} \mathrm{C}$. The mode of inhibition against L. monocytogenes ATCC 15313 was shown to involve a bactericidal effect by treatment with 100 and 200 arbitrary units (AU)/mL of bacteriocin KC24. To test the activity of bacteriocin $\mathrm{KC} 24$ in a food product, bacteriocin KC24 and nisin (100 and $200 \mathrm{AU} / \mathrm{mL}$ ) with $4 \log \mathrm{cfu} / \mathrm{mL}$ of a mixed culture of L. monocytogenes (ATCC 15313, ScottA, H7962, and H7762) were applied to UHT milk. Compared with the control, treatment with bacteriocin KC24 completely inhibited the growth of L. monocytogenes and resulted in no detectable $L$. monocytogenes after $14 \mathrm{~d}$ at $4^{\circ} \mathrm{C}$, whereas nisin moderately inhibited L. monocytogenes, resulting in a final concentration after $14 \mathrm{~d}$ at $4^{\circ} \mathrm{C}$ higher than the initial inoculum. Bacteriocin KC24 may prove useful in improving the safety of dairy products.
\end{abstract}

Key words: bacteriocin, Listeria monocytogenes, UHT milk, biopreservative

\section{Short Communication}

A variety of fermented foods has been screened for lactic acid bacteria with antimicrobial effects. In particular, kimchi is a traditional Korean fermented vegetable food, and has been most frequently studied in screening studies for bacteriocin producers and ap-

Received June 28, 2012.

Accepted September 18, 2012.

${ }^{1}$ Corresponding author: hdpaik@konkuk.ac.kr plications in Korean fermented foods (Kim et al., 2009; Chang and Chang, 2011). Leuconostoc citreum GJ7 was isolated from kimchi and applied to kimchi as a food preservative (Chang and Chang, 2011). Nisin has also been applied to control the ripening of kimchi (Ko et al., 2005).

Bacteriocins are commonly referred to as antibacterial peptides or ribosomally synthesized compounds produced by bacteria, and they are antagonistic to phylogenetically closely related microorganisms (Klaenhammer, 1988). Food safety is an important international concern, and the investigation of novel bacteriocins that target food pathogens has received a great deal of attention. Bacteriocin and bacteriocinproducing strains have been used in dairy products to control Bacillus cereus, Staphylococcus aureus, and Listeria monocytogenes (Gálvez et al., 2007; Bizani et al., 2008; Edalatian et al., 2012).

Listeria monocytogenes is a psychrotrophic foodborne pathogen that has caused outbreaks and sporadic cases of listeriosis worldwide (Reij et al., 2004). Contamination by this microorganism can result in listeriosis in immunocompromised individuals, pregnant woman, children, the elderly, and neonates. Listeria monocytogenes, which is widely distributed in nature, is frequently found in food processing environments, can grow at temperatures ranging from 1 to $45^{\circ} \mathrm{C}$ (Sorrells et al., 1989; Walker et al., 1990), and is highly salttolerant (Farber and Peterkin, 1991). These characteristics make L. monocytogenes difficult to control in the food industry. Therefore, bacteriocins have been investigated in milk, cottage cheese, and meat products to solve this problem (Nieto-Lozano et al., 2006; Chanos and Williams, 2011).

The principal objective of this study was to isolate an antilisterial bacteriocin-producing strain from kimchi and characterize the inherent bacteriocins. Additionally, the obtained bacteriocin was studied as a possible natural preservative against $L$. monocytogenes in UHT milk.

One hundred twenty-five kimchi samples were obtained from homes, local groceries, and restaurants in Seoul and Kyunggi-do, Korea. The isolation method 
used was the triple agar layer method (Lee and Paik, 2001). Two hundred lactic acid bacteria were isolated from kimchi and tested for antimicrobial effects. Only isolate KC24 showed antimicrobial effects when the supernatant was controlled at $\mathrm{pH} 6.5$, indicating that the effect was not due to organic acids. Isolate $\mathrm{KC} 24$ was a gram-positive coccus, identified as Lactococcus lactis at an identity of $99.8 \%$ by $16 \mathrm{~S}$ ribosomal DNA sequence and API 50 CHL kit (bioMérieux, Lyon, France). Therefore, the bacteriocin generated by Lactococcus lactis $\mathrm{KC} 24$ was temporarily named bacteriocin KC24.

Lactococcus lactis KC24 was grown in de Man, Rogosa, and Sharpe (MRS; Becton Dickinson, San Diego, $\mathrm{CA}$ ) broth for $28 \mathrm{~h}$ in a 5 -L jar fermenter controlled to $\mathrm{pH} 6.5$, at $35^{\circ} \mathrm{C}$ and $200 \mathrm{rpm}$. Cell concentration was assessed as cell number (log cfu/mL) on an MRS plate (Becton Dickinson) and optical density (absorbance) at $660 \mathrm{~nm}$. The supernatant was collected via centrifugation $\left(15,130 \times g\right.$ for $20 \mathrm{~min}$ at $\left.4^{\circ} \mathrm{C}\right)$, and filtered through a $0.22-\mu \mathrm{m}$ pore size cellulose acetate filter. Bacteriocin activity was determined by the spot-on-lawn assay (Lee and Paik, 2001). Soft agar (0.8\% agar) seeded with the indicator strain (L. monocytogenes ATCC 15313) was overlaid on the plates and left to solidify. Bacteriocin KC24 samples were serially diluted, $5 \mu \mathrm{L}$ of each dilution was spotted on each plate, and the plates were incubated at $35^{\circ} \mathrm{C}$. Bacteriocin activity $(\mathrm{AU} / \mathrm{mL})=2^{\mathrm{n}}$ $\times 200$, where $\mathrm{n}$ is the final dilution number showing inhibition.

The production of bacteriocin KC24 appeared to follow a kinetic pattern typical of primary metabolite synthesis (Figure 1). The activity of bacteriocin KC24 increased as the culture reached the exponential growth phase and reached a maximum $(6,400 \mathrm{AU} / \mathrm{mL})$ after 4 $\mathrm{h}$ of incubation. Almost all bacteriocins of lactic acid bacteria are generated during the exponential growth phase (Lim, 2010). In addition, the activity of bacteriocin KC24 remained until $20 \mathrm{~h}$ after exponential growth phase. Therefore, bacteriocin KC24 can be harvested in the stationary phase. This comparatively early production of bacteriocin KC24 could be exploited as an industrially useful characteristic.

The antimicrobial spectrum of L. lactis $\mathrm{KC} 24$ supernatant (adjusted to $\mathrm{pH}$ 6.5) was determined using the spot-on-lawn assay. Bacillus cereus KCCM 11341, B. cereus KCCM 40133, Listeria ivanovii ssp. ivanovii KCTC 3444, L. monocytogenes ATCC 15313, Listeria seeligeri KCTC 3591, Micrococcus flavus ATCC 10240, and Staphylococcus aureus KCCM 32395 were sensitive, whereas Escherichia coli O157:H7 and Salmonella Enteritidis KCCM 12021 were insensitive to the supernatant of L. lactis KC24 (data not shown).

Bacteriocin KC24 was partially purified from the culture supernatant by precipitation with $40 \%$ ammo- nium. The effects of enzymes on partial purified bacteriocin $\mathrm{KC} 24$ were assessed via reaction with various proteases at a final concentration of $1 \mathrm{mg} / \mathrm{mL}$ for $1 \mathrm{~h}$ at $35^{\circ} \mathrm{C}$. The proteases used were protease XIV, protease IX, proteinase $\mathrm{K}$, trypsin, $\alpha$-chymotrypsin, and protease XIII. Treatment with protease XIV induced a loss of bacteriocin activity ( $75 \%$ reduction; $P<0.001$ ). The loss of bacteriocin activity was not observed when bacteriocin $\mathrm{KC} 24$ was treated with the other tested enzymes. These results confirmed the proteinaceous nature of the antimicrobial substance.

The effect of heat was assessed by 30 min of heating at $50,60,70,80,90$, and $100^{\circ} \mathrm{C}$ and by autoclaving at $121^{\circ} \mathrm{C}$ for $15 \mathrm{~min}$. Bacteriocin $\mathrm{KC} 24$ proved to be heat-stable: it was stable after $30 \mathrm{~min}$ of heat treatment at $50,60,70,80,90$, and $100^{\circ} \mathrm{C}$, and retained $50 \%$ of bacteriocin activity after autoclaving at $121^{\circ} \mathrm{C}$ for 15 min. This heat stability may be attributable to the formation of small globular structures and the occurrence of strongly hydrophobic regions, stable cross-linkages, and high glycine content (De Vuyst and Vandamme, 1992; Oscáriz and Pisabarro, 2001). Compared with our results, several bacteriocins are reported to remain stable under autoclaving conditions (Luo et al., 2011). Additionally, bacteriocin $\mathrm{KC} 24$ was stable in a $\mathrm{pH}$ range of 3.0 to 9.0. The stability of bacteriocin $\mathrm{KC} 24$ is of particular importance to food industry applications.

To determine whether bacteriocin $\mathrm{KC} 24$ has a bactericidal or bacteriostatic effect, bacteriocin $\mathrm{KC} 24$ was added to indicator cells suspended in $0.1 \mathrm{M}$ potassium phosphate buffer ( $\mathrm{pH}$ 7.0). The mode of inhibition was

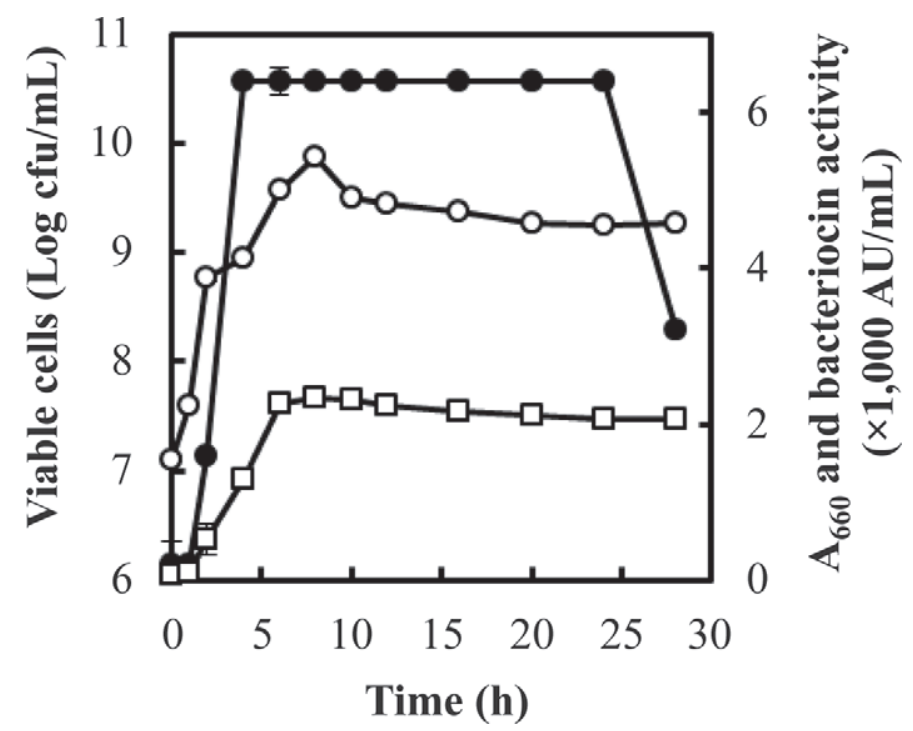

Figure 1. Production of bacteriocin KC24 in 5-L jar fermentor. $\bigcirc$ $=$ viable cells $(\log \mathrm{cfu} / \mathrm{mL}) ; \boldsymbol{0}=$ antimicrobial activity of bacteriocin $\mathrm{KC} 24[\times 1,000$ arbitrary units $(\mathrm{AU}) / \mathrm{mL}] ; \square=$ optical density at 660 $\mathrm{nm}\left(\mathrm{A}_{660}\right)$. 


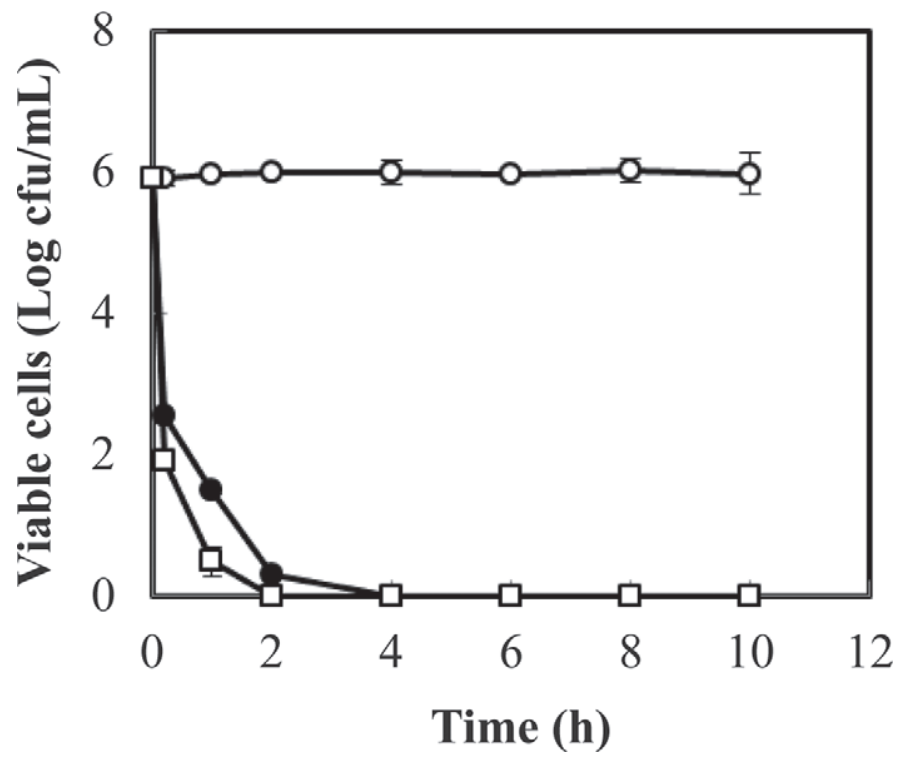

Figure 2. Mode of inhibition of bacteriocin $\mathrm{KC} 24$ on Listeria monocytogenes ATCC 15313. $\bigcirc=$ control; $\bullet=$ tryptic soy broth (TSB) with 50 arbitrary units $(\mathrm{AU}) / \mathrm{mL}$ of bacteriocin $\mathrm{KC} 24 ; \square=$ TSB with $100 \mathrm{AU} / \mathrm{mL}$ of bacteriocin KC24.

determined via treatment with 0,50 , and $100 \mathrm{AU} / \mathrm{mL}$ of bacteriocin KC24. One milliliter of L. monocytogenes ATCC 15313 culture in $9 \mathrm{~mL}$ of $0.1 \mathrm{M}$ potassium phosphate buffer ( $\mathrm{pH} 7.0$ ) containing bacteriocin $\mathrm{KC} 24$ was incubated at $35^{\circ} \mathrm{C}$. Samples were collected at $0,1,2$, $4,6,8$, and $10 \mathrm{~h}$. Viable cells were counted via the general plate counting method on tryptic soy broth (TSB, Becton Dickinson). After 4 h, L. monocytogenes ATCC 15313 exposed to 50 and $100 \mathrm{AU} / \mathrm{mL}$ of bacteriocin $\mathrm{KC} 24$ was not detected (Figure 2). In addition, the cell morphology determined by scanning electron microscopy showed damaged cell membranes (data not shown). Therefore, bacteriocin $\mathrm{KC} 24$ has a bactericidal effect against $L$. monocytogenes ATCC 15313. The antimicrobial mechanism of most bacteriocins is associated with membrane permeabilization (Sirtori et al., 2008; Zhou et al., 2008).

Listeria monocytogenes is capable of surviving and growing on chilled food at temperatures commonly used for refrigeration (Walker et al., 1990). We purchased UHT milk (Seoul Milk, Seoul, Korea) from a local grocery. A mixed culture of $L$. monocytogenes was used, with combination of strains ATCC 15313, ScottA, H7969, and H7762 in 1 L of UHT milk. Controls contained no bacteriocin, and nisin was used as a reference bacteriocin. The final concentrations of bacteriocin $\mathrm{KC} 24$ were 100 and $200 \mathrm{AU} / \mathrm{mL}$, and the same concentrations were used for nisin. Each sample was placed in a $50-\mathrm{mL}$ Falcon tube and stored at $4^{\circ} \mathrm{C}$. Each experiment was conducted in triplicate, and sam-
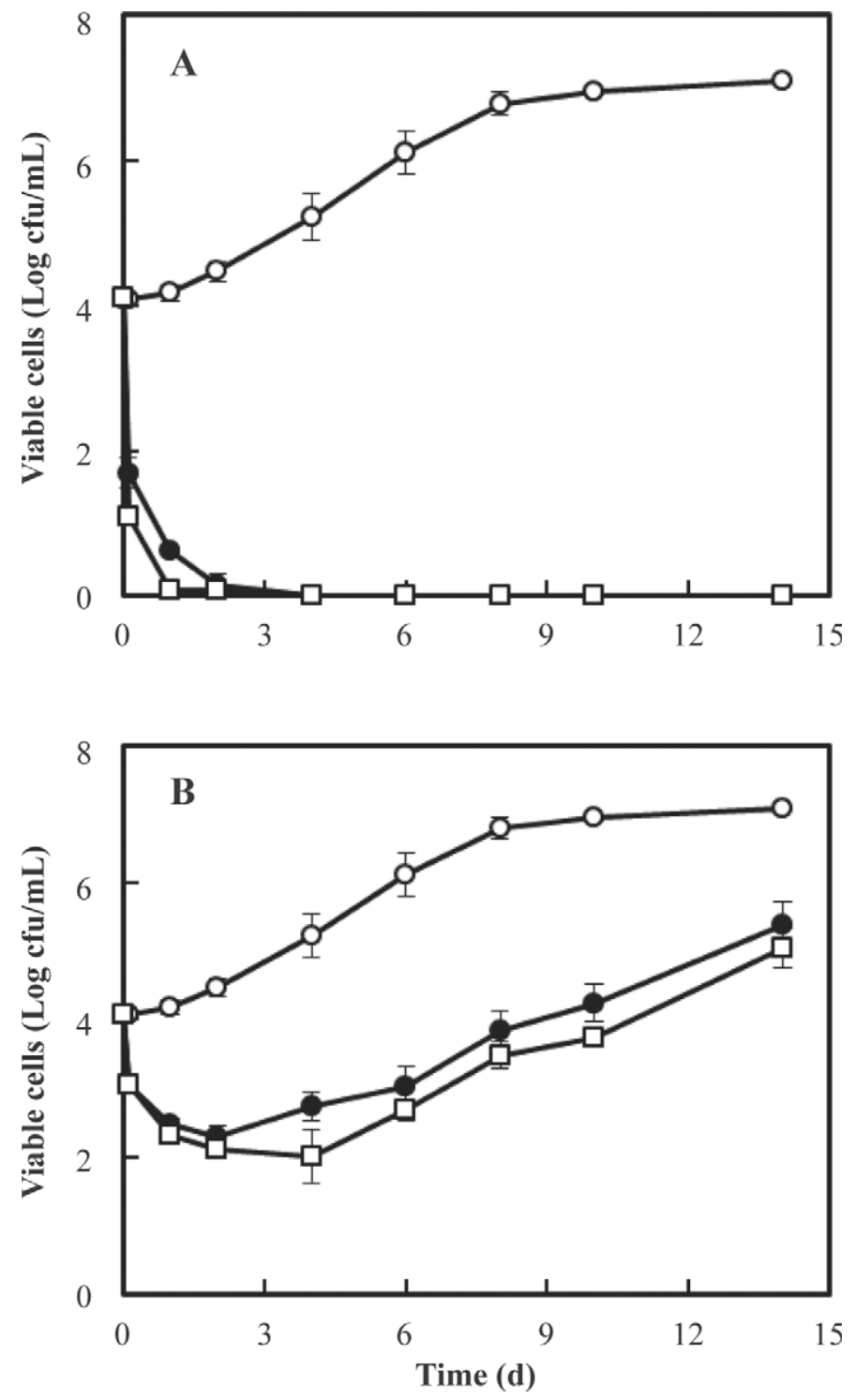

Figure 3. Effect of (A) bacteriocin $\mathrm{KC} 24$ and (B) nisin against Listeria monocytogenes in UHT milk at $4^{\circ} \mathrm{C} . \bigcirc=$ control; $\bullet=$ UHT milk with 100 arbitrary units $(\mathrm{AU}) / \mathrm{mL}$ of bacteriocin (bacteriocin KC24 or nisin); $\square=$ UHT milk with $200 \mathrm{AU} / \mathrm{mL}$ of bacteriocin.

pling times were $0,1,2,4,6,8,10$, and $14 \mathrm{~d}$. Listeria monocytogenes was enumerated via the general plate counting method using Listeria selective medium (BD, Sparks, MD). A significant $(P<0.01)$ decline in the number of viable cells was observed during the storage of UHT milk with 100 and $200 \mathrm{AU} / \mathrm{mL}$ of bacteriocin $\mathrm{KC} 24$, and L. monocytogenes was not detected after $4 \mathrm{~d}$ (Figure 3). Cerein 8A, a bacteriocin produced by Bacillus cereus $8 \mathrm{~A}$, was reported to result in a successive increase in the shelf life of UHT milk, similarly to that observed with bacteriocin KC24 (Bizani et al., 2008). Treatment of UHT milk with $400 \mathrm{AU} / \mathrm{mL}$ of cerein $8 \mathrm{~A}$ 
delayed increase of cell concentrations of $L$. monocytogenes compared with the control without bacteriocin. The viable control cells (without bacteriocin) were increased to $7.1 \log \mathrm{cfu} / \mathrm{mL}$ in the study of Bizani et al. (2008). The UHT milk with nisin showed a decrease of L. monocytogenes to $2 \log \mathrm{cfu} / \mathrm{mL}$ over $2 \mathrm{~d}$. However, L. monocytogenes counts increased to $4.9 \log \mathrm{cfu} / \mathrm{mL}$ after $14 \mathrm{~d}$. The $\mathrm{pH}$ of commercial milk is 6.7, which caused the loss of nisin activity. Similar results in other studies indicate that nisin has unstable activity at $\mathrm{pH}$ $>6.0$. Listeria monocytogenes ATCC 7644 was not detected in yogurt with added nisin $(50 \mathrm{IU} / \mathrm{mL})$ at $\mathrm{pH}$ 4.5; however, a reduction in L. monocytogenes ATCC 7644 of approximately $4 \mathrm{log} \mathrm{cfu} / \mathrm{mL}$ was observed at pH 6.8 after 48 h in nonfat dry milk (Benkerroum et al., 2003). These results show a difference in the stability of bacteriocins in food systems.

Bacteriocin $\mathrm{KC} 24$ was characterized and evaluated for its antilisterial effect in UHT milk for $14 \mathrm{~d}$ at $4^{\circ} \mathrm{C}$. It was demonstrated to be a very stable bacteriocin under a broad $\mathrm{pH}$ range (3.0 to 9.0 ) and temperature range $\left(50-121^{\circ} \mathrm{C}\right)$. Listeria monocytogenes added to UHT milk treated with bacteriocin $\mathrm{KC} 24$ was nondetectable after $14 \mathrm{~d}$ of refrigerated storage, indicating the stable nature of the bacteriocin. These characteristics indicate that bacteriocin $\mathrm{KC} 24$ may be applied as a natural food preservative in dairy products.

\section{ACKNOWLEDGMENTS}

This study was supported by the Priority Research Centers Program (Seoul, Korea) through the National Research Foundation of Korea funded by the Ministry of Education, Science and Technology (2009-0093824).

\section{REFERENCES}

Benkerroum, N., H. Oubel, and W. E. Sandine. 2003. Effect of nisin on yogurt starter, and survival of Listeria monocytogenes during fermentation and storage of yogurt. Internet J. Food Safety 1:1-5.

Bizani, D., J. A. C. Morrissy, A. P. M. Dominguez, and A. Bradelli. 2008. Inhibition of Listeria monocytogenes in dairy products using the bacteriocin-like peptide cerein 8A. Int. J. Food Microbiol. 121:229-233

Chang, J. Y., and H. C. Chang. 2011. Growth inhibition of foodborne pathogens by kimchi prepared with bacteriocin-producing starter culture. J. Food Sci. 76:M72-78.
Chanos, P., and D. R. Williams. 2011. Anti-listeria bacteriocin-producing bacteria from raw ewe's milk in northern Greece. J. Appl. Microbiol. 110:757-768.

De Vuyst, L., and E. J. Vandamme. 1992. Influence of the carbon source on nisin production in Lactococcus lactis ssp. lactis batch fermentations. J. Gen. Microbiol. 138:571-578.

Edalatian, M. R., M. B. Habibi Najafi, S. A. Mortazavi, Á. Alegría, S. Delgado, M. R. Bassami, and B. Mayo. 2012. Production of bacteriocins by Enterococcus spp. isolated from traditional, Iranian, raw milk cheese, and detection of their encoding genes. Eur. Food Res. Technol. 234:789-796.

Farber, J. M., and P. I. Peterkin. 1991. Listeria monocytogenes, a foodborne pathogen. Microbiol. Rev. 55:476-511.

Gálvez, A., H. Abriouel, R. L. López, and N. B. Omar. 2007. Bacteriocin-based strategies for food biopreservation. Int. J. Food Microbiol. 120:51-70.

Kim, M., S. J. Lee, K. J. Seul, Y. M. Park, and S. Y. Ghim. 2009 Characterization of antimicrobial substances produced by Lactobacillus plantarum KNUC25 isolated from kimchi. Kor. J. Microbiol. Biotechnol. 37:24-32.

Klaenhammer, T. R. 1988. Bacteriocins of lactic acid bacteria. Biochimie 70:337-349.

Ko, S., H. S. Kim, S. C. Jo, S. H. Cho, W. S. Park, and S. C. Lee. 2005. Evaluation of pH-sensitive Eudragit E100 microcapsules containing nisin for controlling the ripening of Kimchi. Food Sci. Biotechnol. 14:358-362

Lee, N. K., and H.-D. Paik, 2001. Partial characterization of lacticin NK24, a newly identified bacteriocin of Lactococcus lactis NK24 isolated from jeot-gal. Food Microbiol. 18:17-24.

Lim, S. M. 2010. Cultural conditions and nutritional components affecting the growth and bacteriocin production of Lactobacillus plantarum KC21. Food Sci. Biotechnol. 19:793-802.

Luo, F., S. Feng, Q. Sun, W. Xiang, J. Zhao, J. Zhang, and Z. Yang. 2011. Screening for bacteriocin-producing lactic acid bacteria from kurut, a traditional naturally fermented yak milk from QinghaiTibet plateau. Food Contr. 22:50-53.

Nieto-Lozano, J. C., J. I. Reguera-Useros, M. C. Peláez-Martínez, and A. Hardisson de la Torre. 2006. Effects of a bacteriocin produced by Pediococcus acidilactici against Listeria monocytogenes and Clostridium perfringens on Spanish raw meat. Meat Sci. 72:57-61.

Oscáriz, J. C., and A. G. Pisabarro. 2001. Classification and mode of action of membrane-active bacteriocins produced by gram-positive bacteria. Int. Microbiol. 4:13-19.

Reij, M. W., E. D. Den Aantrekker, and ILSI Europe Risk Analysis in Microbiology Task Force. 2004. Recontamination as a source of pathogens in processed foods. Int. J. Food Microbiol. 91:1-11.

Sirtori, L. R., A. S. Motta, and A. Bradelli. 2008. Mode of action of antimicrobial peptide $\mathrm{P} 45$ on Listeria monocytogenes. J. Basic Microbiol. 48:393-400.

Sorrells, K. M., D. C. Enigl, and J. R. Hatfield. 1989. Effect of pH, acidulant, time, and temperature on the growth and survival of Listeria monocytogenes. J. Food Prot. 52:571-573.

Walker, S. J., P. Archer, and J. G. Banks. 1990. Growth of Listeria monocytogenes at refrigeration temperatures. J. Appl. Bacteriol. 68:157-162.

Zhou, K., W. Zhou, P. Li, G. Liu, J. Zhang, and Y. Dai. 2008. Mode of action of pentocin 31-1: An antilisteria bacteriocin produced by Lactobacillus pentosus from Chinese traditional ham. Food Contr. 19:817-822. 